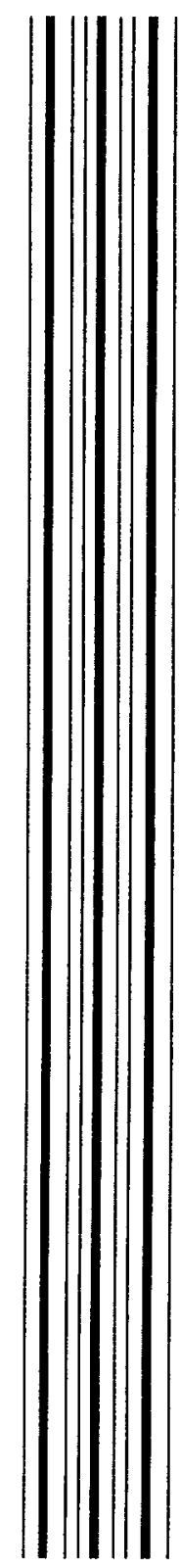

UCRL-ID-151953

\title{
Radiological Conditions on Rongelap Atoll: Recommendations for Visiting and Food Gathering on the Northern Islands of Rongelap Atoll
}

\author{
T.F. Hamilton
}

February 20, 2003

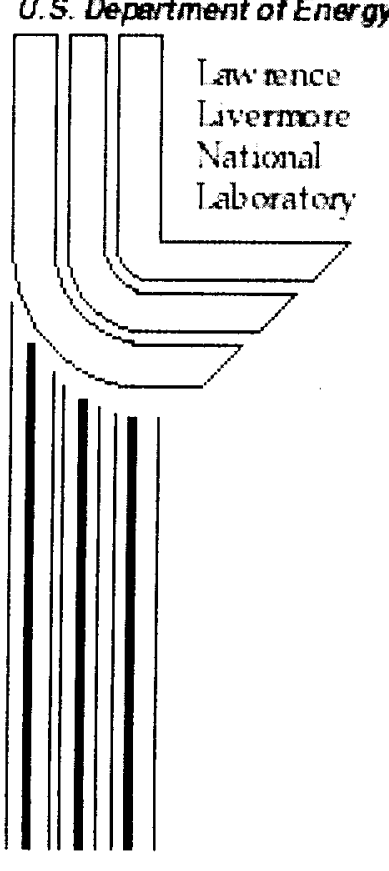




\section{DISCLAIMER}

This document was prepared as an account of work sponsored by an agency of the United States Government. Neither the United States Government nor the University of California nor any of their employees, makes any warranty, express or implied, or assumes any legal liability or responsibility for the accuracy, completeness, or usefulness of any information, apparatus, product, or process disclosed, or represents that its use would not infringe privately owned rights. Reference herein to any specific commercial product, process, or service by trade name, trademark, manufacturer, or otherwise, does not necessarily constitute or imply its endorsement, recommendation, or favoring by the United States Government or the University of California. The views and opinions of authors expressed herein do not necessarily state or reflect those of the United States Government or the University of California, and shall not be used for advertising or product endorsement purposes.

This work was performed under the auspices of the U. S. Department of Energy by the University of California, Lawrence Livermore National Laboratory under Contract No. W-7405-Eng-48.

This report has been reproduced directly from the best available copy.

Available to DOE and DOE contractors from the Office of Scientific and Technical Information

P.O. Box 62, Oak Ridge, TN 37831

Prices available from (423) 576-8401

http://apollo.osti.gov/bridge/

Available to the public from the National Technical Information Service

U.S. Department of Commerce 5285 Port Royal Rd., Springfield, VA 22161 http://www.ntis.gov/

OR

Lawrence Livermore National Laboratory

Technical Information Department's Digital Library http://www.llnl.gov/tid/Library.html 
Radiological Conditions on Rongelap Atoll

\section{Recommendations for visiting and food gathering on the northern islands of Rongelap Atoll.}

Rongelap Atoll experienced close-in or local fallout from the U.S. nuclear test program conducted in the northern Marshall Islands between 1946 and 1958. By all internationally agreed scientific criteria, Rongelap Island is considered safe for permanent resettlement. However, the amount of bombrelated radioactivity in soil and vegetation is, on average, about 5 times greater in the northern islands of the atoll because the centerline of the fallout pattern from the 1954 thermonuclear "Bravo" test extended over this part of the atoll.

The most important radioactive element remaining on the atoll is radioactive cesium (cesium-137). Cesium-137 emits what is called a "gamma ray" that can penetrate the body and deliver both an external (outside the body) and internal (from inside the body) gamma dose to inhabitants of Rongelap Atoll. Cesium-137 is taken up from the soil into locally grown foodstuffs such as coconut, Pandanus and breadfruit. Significant quantities of cesium-137 may also be found in coconut crab. The internal dose delivered to people eating these products will be directly proportional to the concentration of cesium137 in the food and the amount consumed. The external gamma dose will depend on the concentration of cesium-137 in the soil and the amount of time spent in the area. The highest concentration of cesium-137 in surface soils of the northern islands of Rongelap Atoll is about equivalent to that measured on Bikini Island. Under the radiation protection criteria adopted by the Republic of the Marshall Islands' Nuclear Claims Tribunal, permanent resettlement of these islands would require intervention because of the higher radiation doses that could potentially be delivered to inhabitants living on a diet derived largely from local foods. A more realistic lifestyle scenario is that the resettled population on Rongelap Island will occasionally visit the northern part of the atoll for food gathering, fishing and other recreational activities.

It is estimated that a person spending 8 hours ( 1 work day) in the interior of the Rongelap Atoll northern islands will receive a maximum additional external dose of around 0.1-0.2 mrem per day. Furthermore, Lawrence Livermore National Laboratory's environmental monitoring continues to show that the marine environment contains very low levels of bomb radioactivity. Similarly, the occasional consumption of terrestrial foods including coconut crab from the northern islands is not expected to add 
significantly to the radiological health risk of living on Rongelap Island. ${ }^{1}$ The average annual effective ingestion dose for Rongelap Island resettlement in 2002 is estimated to be around 1-2 mrem per year when imported foods are made available and proposed remediation efforts take effect. ${ }^{2}$ This estimate is about twice that of the Rongelap Island resettlement worker population using direct measurements from the whole body counting program. ${ }^{3}$ Resettlement workers presently living on the islands receive an average internal dose from cesium-137 of less than 1 mrem $(0.01 \mathrm{mSv})$ per year. These workers are known to eat locally grown foods and coconut crabs collected from the northern islands. The highest individual dose observed was $4 \mathrm{mrem}(0.04 \mathrm{mSv})$ per year.

Under the guidelines adopted by the Republic of the Marshall Islands Nuclear Claims Tribunal, it is concluded that diving, fishing and visiting any northern island of Rongelap Atoll are safe activities for limited periods. Eating local fish and other marine life such as clams would also be considered safe.

Consumption of plant foods from the northern islands of Rongelap Atoll depends on successful implementation of specific remediation measures to ensure dietary intakes of cesium-137 remain at or below levels considered safe. The whole body counting program should continue to monitor the actual internal levels of cesium-137 among people eating plants and coconut crabs gathered from the northern islands of Rongelap Atoll islands until such time that the Nuclear Claims Tribunal guidelines are met.

Terry Hamilton

Lawrence Livermore National Laboratory

\footnotetext{
${ }^{1}$ The ingestion dose that people receive could increase 5 or 6 times if local residents use the northern islands for food gathering under existing conditions for 1 in every 10 days. This is a very conservative assumption because of the limited amount of available foods growing on the northern islands.

${ }^{2}$ Robison W and others (1994). An updated Dose Assessment for Rongelap Island, UCRL-LR-107036, Lawrence Livermore National Laboratory.

${ }^{3}$ The presence of cesium-137 in the human body can be detected and measured using a device called a whole body counter. A person relaxes in a chair for a few minutes while counts or measurements are taken using a detector a few inches away from the body. The Rongelap Local Government in cooperation with the U.S. Department of Energy (DOE) constructed a whole body counting facility on Rongelap Island. Rongelap technicians who receive supervision and training from scientists from the Lawrence Livermore National Laboratory (LLNL) operate the whole body counters. The facility permits resettlement workers living on Rongelap Island to check the amount of cesium-137 in their bodies.
} 